\title{
Interview with Reinhard Flender, director of the Peermusic Classical
}

Entretien avec Reinhard Flender, directeur de Peermusic Classical

Interview met Reinhard Flender, directeur van de Peermusic Classical

\section{Reinhard Flender}

\section{(2) OpenEdition}

\section{Journals}

Electronic version

URL: http://journals.openedition.org/temoigner/1250

DOI: 10.4000/temoigner.1250

ISSN: 2506-6390

\section{Publisher:}

Éditions du Centre d'études et de documentation Mémoire d'Auschwitz, Éditions Kimé

\section{Printed version}

Date of publication: 1 October 2014

Number of pages: $32-33$

ISBN: 978-2-84174-674-3

ISSN: 2031-4183

\section{Electronic reference}

Reinhard Flender, «Interview with Reinhard Flender, director of the Peermusic Classical », Témoigner. Entre histoire et mémoire [Online], 118 | 2014, Online since 01 October 2015, connection on 23 October 2020. URL : http://journals.openedition.org/temoigner/1250 ; DOI : https://doi.org/10.4000/ temoigner. 1250 


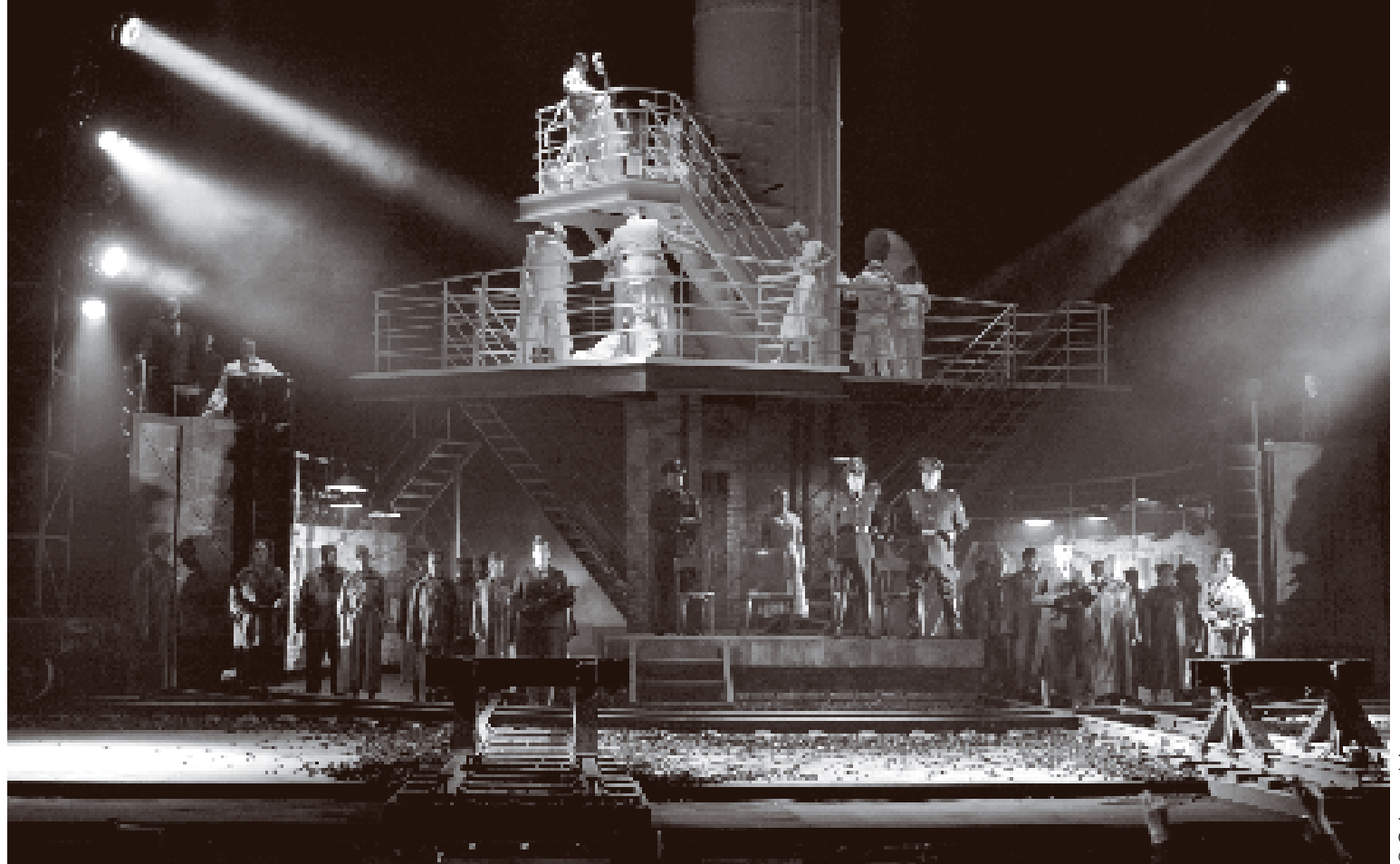

\section{THE PASSENGER,} AN OPERA

\section{OPERA FROM OUT OF PURGATORY}

In the previous edition of Testimony, we devoted our chronicle to The Emperor of Atlantis by Viktor Ullmann. This time, we would like to look at another opera, again one that is not very well-known: The Passenger by Mieczyslaw Weinberg. Its last performance, in London, aroused a few debates.

\section{$\rightarrow$ In association with $\quad$ ResMusica}

What is precisely remarkable is Weinberg's capacity to manage his time, the progressive building of tension, the economy of music thus marking the difficult time in the camp, counterbalanced by orchestral and vocal bursts that draw the spectator in.

her husband and revives the episodes of her ambiguous and domineering relationship with the pisoner. At the performance on 20 September in London, English critics from The Guardian to The Financia Times, from The Evening Standard to The Telegrap he the sted wing and the commitment of the quality one the staging and the conniture critic reckons that the work is a "tol du," wh. One cric reckons that the work is a total dud", wherees wish to spend an evening tha wout the send an eve

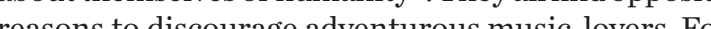
reans to discourage adventurous music-lovers. For ex anject", while others bammer "ther sict music to interest music-lovers!" Regerding though music to interest nusitover. resentation of Auschwitz on stage? Some say it is too Enstich othrs find it too dranatized. Essentially, English newspapers spontaneously offered the same analysis as the careftlly deliberated one of Bolsho

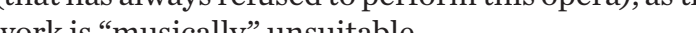
" is "musically" unsuitable.

the explained? Indeed, the first act is slowly set, beginning with the and figuratively) into the hell of Auschwitz Adnit and the second act follows and exanin. Ad tedy, hhe second act follows and examines in detail at the same time with a musical and lyical inbined What some time with a musical and lyrical intensity. manage his time, the progressive building of tension, the economy of music thus marking the difficult time in the camp counterbalanced by orchestral and vocal bursts that draw the spectator in

From listening and studying the music sheets, 作 3 Babi Yar and a friend werther

Yes, the concentration camps challenge the very

Yes, the concentration camps challenge the very question of the irreptionsentability of extrene viocise. Yes, its a question of finding a particularly precise approach so as not to falleither into an un voyentisn, or into an unbearable sense of pathos. The ll care "I allcaricature. "LisatheSs" wing we mare cono and interesting than her diplowat his che chos ber to wife's and his country'spast, not for her sake, Wh presue his own reputation and social status.

In this London performance Michelle Breedt

In this Lonlon performance, Michelle Breed prod an excellon Lisa, just as good as the version Marta was ex ceptional She astounds us with her che of and is of

is of an overw diringstrength.

Tichard Armstron brought proper proper to the narration. Thestaging by David Pountney ban-and-for movement between the deck the liner an the flo and goings of the wagons that in turn serve as the

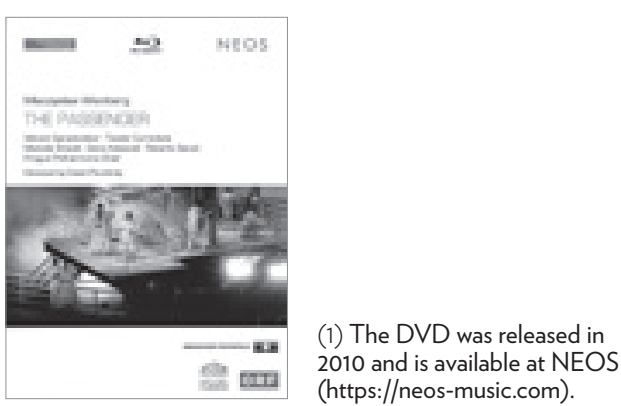


barracks, the walls of the camp and as a reminder of the crematorium furnaces.

An addition to the opera in comparison to the book the character of the Tadeusz, the fiancé and violinist brings a dramatic climax at the end of the opera: summoned to play a vulgar waltz for the head of the camp an is a Nazi acolytes, he interprets Chaconne by Bach. th is a lesson and a challenge set by the artist, highly know against impostors in uniform. He paid with his life for his provocation. This theme of the prisoner defendit is not a fictional invention. It echoes the Tering it, is not a fictional invention. It echoes the Terezin Requiem by Josef Bor that tells the true story of conductor Raphaèl Schächter who managed to practize and to perform Verlis Requiem in front of Eichman A book about guilt

ut guilt, the incomprehension of other and of oneself (Lisa seems sincere when she complain to her husband that she was hated by all the prisoners), memory, The Passenger is also a reflection on love, the necsity or holding onto one's moral values and onto culture like a challenge that is both derisory and upreme a and pure moment of opera, carried out magnificently, bout a the that can to be moyed A few more than forty years to be played. A few more years of patience are

At the end of the performance, a slender elderly woman approached to pay tribute, cautiously crossinitial text, wholived and survived Auschitz of the "knew" Lis Yes, the Marta of thed Auschwitz and who "knew Lisa. Yes, the Martaotheopera is still allive and by her work and by hre pres she is telling us that Jean-Christophe Le Toqui (Translation: Sarah Voke) This text is an adapted and updated version of the chronicle
dating from 20 September 2011 written by Jean-Christophe Le Toquin
and published in Res Musica.

The opera was performed on 10 July 2014 in the Lincoln Center
in New York: http:///culture.pl//en//article/operatic-holocaust-onstage-

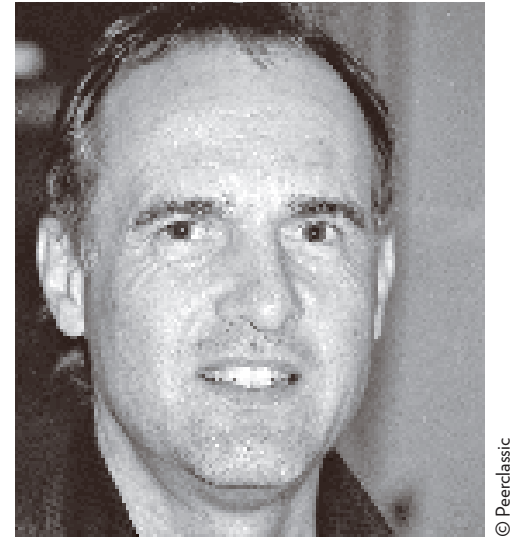

Interview with..

Reinhard Flender, director of the Peermusic Classical

Peermusic Classical is the European

classical music branch of the Peermusic

group that was founded in 1928 and that is today the largest music editor worldwide

with 600,000 works in its catalogue.

ResMusica met with its director

Reinhard Flender regarding The Passenger by Weinberg.

ResMusica. Mieczyslaw Weinberg is today part of the most important composers of your catalogue. How did you discover this composer who forged most of his caree Reinhard Flender: It

Reinhard Flender: It was from the Quatuor Danel in 1999, and the first movement of the Quartet No.7. At first I was not very impressed, because this movement taken on its own doesn't reveal who Weinberg is. It was with the Quintette that I decided to go to Moscow. Thirty works had been published by Sikorski, and al the rest was available. It was important to move quickly, because it had in in was interested

And The Passenger?

Reinhard Flender: It was only later that I heard of an opera with a theme, how can I put it... that has some- thing to do with us, that concerned Germans. I was highly impressed by the sheet music, written with such intensity. And there also exists a recording where Weinberg himself sings the entire opera whilst playing the piano. We understand that he had everything in his mind!

How was the opera organised, and why in Bregenz? Reinhard Flender: I made a proposition to every opera house, including Bregenz. David Pountney, whom had never met, was the director of this festival. I was shocked when he immediately replied: "We will do I unders. Bring me the nhusc." It was later hat and spoke Russian. It was a wodsend. He wountry and spoke Russian. It was a godsend. He worked as money. He was we to Auschwitz and spent a lot of the time the weized by a passion for the opera. At the tint bought the all and, in 2006, the opera was played as loved it inmediately. He loved it immediately.

\section{Because of its libretto?}

Reinhard Flonder: The fact that Marta (namely Zofia Posmysz, the author of the source text, see supra) is Posmysz, the author of the source text, see supra) is
still alive, added something. Her book is incredible, very rich and not polemic. There were many theories. Shostakovich could have read Zofia's book and given it to Weinberg, though nothing is certain. The final scene, to Were Tade whe Taltz is an ide tro Chacon by Medvedev. Zofia was not so happy about this, but it was necessary.

Weinberg composed eight operas, The Passenger being the first. What place does this opera hold in the being the first. What

Reinhard Flender: We already knew that The Passenger was key to his work. Weinberg said himself that ger was key to his work. Weinberg said himself that
everything was tied to it, everything he wrote before everything was tied to it, every hing he wiote before and after. The more we knowhis symphonies, hemore we see that there is incredible command in the opera. counter the theme of Leningrad by Shosta. We counter the the of Leningrad by Shostakovich and quotes of Kurt Weill. The most revolutionary is in the shack scenes. Each time the German soldiers enter, wehear the initial theme of Beethoven's Fith, altered, militarized. This systematic association of the arny

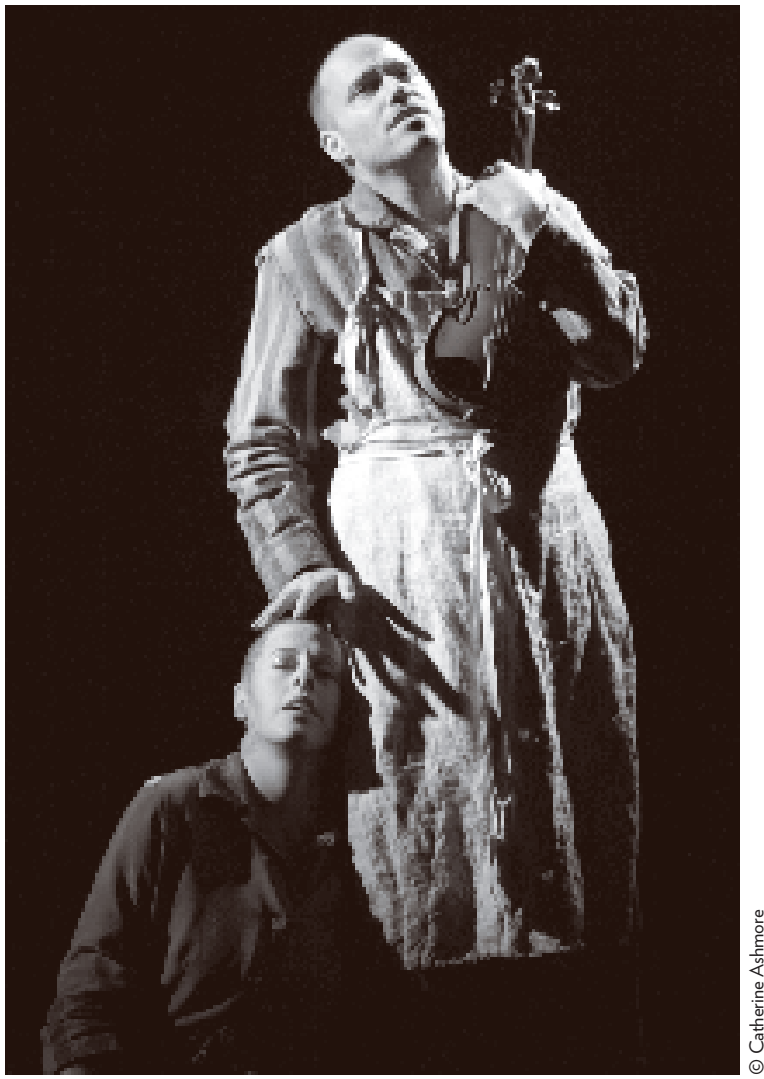

were aware of it, they would make it clearer. There are lso many quotes, which require an in-depth analysis to be heard. And, as Bach quotes himself in his Passions, Weinberg recycles material.

The work was played in Bregenz, Warsaw and now in London. Did they have different approaches?

Render: The English musicians played with more individuality, I heard details that I had never previously noticed. It was impressive.

Do you know what is next?

Reinhard Flender: The next interpretation will be in Karlsruhe, with a new production. And then in Tel Aviv, Houston, New York. I was unable to find an opera house that was interested in France and I wonder why... 17 October 2011 by Jean-Christophe Le Toquin 